\title{
In vitro antioxidant and cholinesterase inhibitory activities of Elatostema papillosum leaves and correlation with their phytochemical profiles: a study relevant to the treatment of Alzheimer's disease
}

\author{
A. S. M. Ali Reza', Mohammad Shahadat Hossain', Sharmin Akhter², Md. Rezanur Rahman², Mst. Samima Nasrin', \\ Md. Josim Uddin', Golam Sadik ${ }^{3}$ and A. H. M. Khurshid Alam ${ }^{3 *}$
}

\begin{abstract}
Background: Alzheimer's disease (AD), one of the major causes of dementia, is an overwhelming neurodegenerative disease that particularly affects the brain, leading to memory loss and impairment of language and judgment capacity. The aim of the present study was to investigate the antioxidant and anticholinesterase properties of the leaves of Elatostema papillosum (EPL) and correlate with their phytochemical profiles, which are relevant to the treatment of AD.

Methods: The dried coarse powder of EPL was extracted with 80\% methanol (EPL-M80) by cold extraction method. The resultant EPL-M80 was assessed for acetylcholinesterase (AChE) and butyrylcholinesterase (BChE) inhibitory activity by the Ellman method. The antioxidant activity was determined by DPPH (1, 1-diphenyl-2-picrylhydrazyl) and hydroxyl radical scavenging assays. Quantitative phytochemical (phenolic and flavonoid contents) analysis of endogenous substances in EPL-M80 was performed by standard spectrophotometric methods.

Results: EPL-M80 significantly $\left(p<0.05\right.$ ) inhibited AChE and BChE activity with $I C_{50}$ of $165.40 \pm 4.01$ and $213.81 \pm 3.57 \mu \mathrm{g} / \mathrm{mL}$, respectively in a dose-dependent manner. Additionally, EPL-M80 exhibited strong radical scavenging activity against $\mathrm{DPPH}\left(\mathrm{IC} \mathrm{C}_{50}=32.35 \pm 0.68 \mu \mathrm{g} / \mathrm{mL}\right)$ and hydroxyl radical $\left(I C_{50}=19.67 \pm 1\right.$. $42 \mu \mathrm{g} / \mathrm{mL}$ ) when compared to that of standards. EPL-M80 was found to be rich in phenolic (23.74 mg gallic acid equivalent/g of dry extract) and flavonoid (31.18 mg quercetin equivalent/g of dry extract) content. Furthermore, a positive correlation $(p<0.001)$ was observed between the total phenolics and antioxidant as well as the anticholinesterase potential.
\end{abstract}

Conclusions: The marked inhibition of AChE and BChE, and potent antioxidant activity of the leaves of Elatostema papillosum highlight its potential to provide an effective treatment for AD.

Keywords: Alzheimer's disease, Cholinesterase inhibitors, Elatostema papillosum, Antioxidant activity

* Correspondence: khurshid.jaist@gmail.com

${ }^{3}$ Department of Pharmacy, University of Rajshahi, Rajshahi 6205, Bangladesh

Full list of author information is available at the end of the article

(c) The Author(s). 2018 Open Access This article is distributed under the terms of the Creative Commons Attribution 4.0 International License (http://creativecommons.org/licenses/by/4.0/), which permits unrestricted use, distribution, and reproduction in any medium, provided you give appropriate credit to the original author(s) and the source, provide a link to the Creative Commons license, and indicate if changes were made. The Creative Commons Public Domain Dedication waiver (http://creativecommons.org/publicdomain/zero/1.0/) applies to the data made available in this article, unless otherwise stated. 


\section{Background}

Alzheimer's disease (AD), one of the leading causes of dementia, is an overwhelming neurodegenerative disease that particularly affects brain function, resulting in memory loss and impairment of language and judgment capacity. A considerable proportion of the advanced age population suffer from $A D$ and early-onset forms of the disease can affect the younger population too [1]. AD is characterised by the formation of senile plaques composed of amyloid beta protein $(A \beta)$, the formation of neurofibrillary tangles (NFT) and substantial loss of both cholinergic and cortical neurons [2, 3]. It has been reported that loss of the neurotransmitter acetylcholine is responsible for the total dysfunction of cholinergic neurotransmission that is observed in $\mathrm{AD}$ and which accounts for cognitive deficits [4]. Acetylcholinesterase is the primary enzyme responsible for the breakdown of acetylcholine within synapses of the cerebral cortex. Consequently, acetylcholinesterase inhibitors can be employed for the treatment of AD [5, 6].

Reactive oxygen species (ROS) are generated within the body by multiple metabolic processes and through the effects of a range of external factors [7]. The aberrant accumulation of ROS has been found in several chronic diseases, including $\mathrm{AD}$ suggesting that ROS may contribute to the pathogenesis of these diseases by inducing oxidative stress $[8,9]$. The antioxidative defense system functions to counteract the potentially damaging effects of oxidative stress by the production of antioxidants to eradicate excess oxidants $[10,11]$. Previous studies have revealed that antioxidants have significant potential to reduce the symptoms and incidence of $\mathrm{AD}[12,13]$. However, the availablity of acetylcholinesterase inhibitors is limited to only a few members that are currently used only for symptomatic treatment and have several adverse effects [1417]. Additionally, synthetic antioxidants have been utilized but have also exhibited adverse side effects that include liver damage and carcinogenesis [18]. Natural sources, especially plants, provide a diverse and largely untapped reservoir of substrates for drug discovery and offer great potential for the development of new cholinesterase inhibitors and antioxidants. Previous studies have already highlighted the potential of plants as vital sources for cholinesterase inhibitors and antioxidants $[6,19]$.

Elatostema papillosum Wedd. (E. papillosum) is a suberect herb (commonly known as Elya) that belongs to the Urticaceae family. Many Elatostema species are distributed in Africa, Asia, Australia and Oceania [20]. E. papillosum is found throughout China, Bhutan, India and Bangladesh. It was previously reported that crushed E. papillosum plants are used in traditional medicine for the treatment of hysteria and abdominal pain [21]. To the best of our knowledge, although there has been no reported pharmacological effect of E. papillosum; in our traditional medicine, the plant, has widely been used by local practitioner against various diseases, including hysteria [21], which is characterized by psychological disorder whose symptoms are closely associated with Alzheimer's disease [22], encouraged us to carry out the pharmacological activity of this plant in this study. Therefore, the objective of this study was to assess the antioxidant and anticholinesterase activities of E. papillosum leaves (EPL), in order to determine its relevance for the treatment of AD.

\section{Methods \\ Chemicals}

Aluminium chloride, ammonium molybdate, ascorbic acid (AA), bicinchoninic acid, DPPH, Folin-Ciocalteu reagent, Tris- $\mathrm{HCl}$ and Triton $\mathrm{X}-100$ were obtained from Sigma-Aldrich (Bangalore, India). Gallic acid (GA) was obtained from Wako Pure Chemical Company Ltd. (Osaka, Japan). 2-deoxy-D-ribose, thiobarbituric acid, (+)-catechin, 5,5-dithio-bis-(2-nitro) benzoic acid, acetylthiocholine iodide and donepezil were obtained from Sigma-Aldrich (Tokyo, Japan). Unless otherwise specified, all other chemicals were of analytical grade.

\section{Collection of plant}

The EPL (leaves of E. papillosum) were collected from the Chittagong district, Bangladesh, and identified by Dr. Sheikh Bokhtear Uddin, taxonomist and professor, Department of Botany, University of Chittagong. A voucher specimen was submitted to the herbarium of the Department of Pharmacy, International Islamic University Chittagong, Chittagong, Bangladesh.

\section{Methanol extract}

The EPL were dried at room temperature (RT) and crushed into fine powder to be used for extraction. Powdered leaves $(500 \mathrm{~g})$ were placed in a bottle and soaked in $80 \%$ methanol. The contents were sealed in the bottle for 7 days with occasional shaking and stirring. The whole mixture was filtered through cotton and Whatman No. 1 filter paper and the filtrate was concentrated with a rotary evaporator under reduced pressure at $50{ }^{\circ} \mathrm{C}$ to obtain $11.48 \mathrm{~g}$ of crude methanol extract of leaves of E. papillosum (EPL-M80).

\section{Experimental animals}

Six to seven week-old Wistar albino rats weighing 150-200 g of both male and female were collected from International Center for Diarrheal Diseases Research, Bangladesh (ICDDRB) and housed in polypropylene cages under controlled conditions. The animals were exposed to alternative 12:12 $\mathrm{h}$ light and dark cycle at an ambient temperature of $26 \pm 2{ }^{\circ} \mathrm{C}$. 
Animals were allowed free access to drinking water and pellet diet, collected from ICDDRB, Dhaka. Rats were acclimatized for 7 days in the laboratory environment prior to the study.

\section{Ethics approval and consent to participate}

The set of rules followed for rats experiment were approved by the Rajshahi University Animal Ethical committee (27/08/RUBCMB), according to governmental guidelines [23]. This research work was approved by Ethical Review Committee for rats of Research Cell of Rajshahi Medical College, Bangladesh (ref. RMC/ER/2010-2013/01).

\section{Euthanasia method}

Compassion, professional ethics, and public sensitivity require that animals are euthanized humanely and appropriately under both planned and emergent situations. According to the 2013 AVMA Guidelines for the Euthanasia of Animals, intraperitoneal injection of ethanol is "acceptable with conditions" for use in rat [24]. Moreover, according to the method described by AllenWorthington et al., 2015 [25], we applied 70\% ( $v / v)$ ethanol in $0.9 \%$ sterile saline in the ventral chest region for getting deep anesthesia.

\section{Determination of total phenolic content}

The total phenolic content was determined by the spectrophotometric method [26]. In brief, $1 \mathrm{~mL}$ of sample (1 $\mathrm{mg} / \mathrm{mL}$ ) was mixed with $1 \mathrm{~mL}$ of Folin-Ciocalteu's phenol reagent. After $5 \mathrm{~min}$ of incubation at RT, $10 \mathrm{~mL}$ of a $7 \%$ $\mathrm{Na}_{2} \mathrm{CO}_{3}$ solution was added to the mixture followed by the addition of $13 \mathrm{~mL}$ of deionized distilled water and mixed thoroughly. The mixture was kept in the dark for 90 min at $23^{\circ} \mathrm{C}$, after which the absorbance was measured at $750 \mathrm{~nm}$. The total phenolic content was determined from extrapolation of a calibration curve which was made by preparing gallic acid (GA) solution. The estimation of the phenolic compounds was carried out in triplicate. The total phenolic content was expressed as milligrams of gallic acid equivalents (GAE) per $g$ of dried sample.

\section{Determination of total flavonoid content}

The total flavonoid content was estimated by the aluminum chloride method described by Yang et al. [27]. The EPL-M80 $(0.5 \mathrm{~mL})$ was mixed with $2.5 \mathrm{~mL}$ of distilled water and $150 \mu \mathrm{L} \mathrm{NaNO}$ solution (5\%). The contents were vortexed for $10 \mathrm{~s}$ and left at RT for $5 \mathrm{~min}$. Then, $300 \mu \mathrm{L} \mathrm{AlCl}_{3}$ (10\%), $1 \mathrm{~mL} \mathrm{NaOH}(1 \mathrm{mM})$ and 550 $\mu \mathrm{L}$ of distilled water were added. The solution was mixed well and kept for $15 \mathrm{~min}$ at RT. The absorbance of each sample was measured at $510 \mathrm{~nm}$. Catechin (CA) concentrations ranging from $31.25-500.00 \mu \mathrm{g} / \mathrm{mL}$ were prepared and the standard calibration curve was obtained. The total flavonoid content was calculated using standard CA calibration curve. The results were expressed as milligrams of catechin equivalents (CAE) per g of dry extract.

\section{Determination of DPPH radical scavenging activity}

The free radical scavenging activity of the EPL-M80 was measured by in vitro DPPH assay according to the method described earlier $[28,29]$. The stock solution was prepared by dissolving $24 \mathrm{mg} \mathrm{DPPH}$ with $100 \mathrm{~mL}$ methanol and stored at $20{ }^{\circ} \mathrm{C}$ until required. The working solution was obtained by diluting DPPH solution with methanol to attain an absorbance of about $0.98 \pm 0.02$ at $517 \mathrm{~nm}$ using the spectrophotometer. A $3 \mathrm{~mL}$ aliquot of this solution was mixed with $100 \mu \mathrm{L}$ of the sample at various concentrations $(10-100 \mu \mathrm{g} / \mathrm{mL})$. The reaction mixture was shaken well and incubated in the dark for $15 \mathrm{~min}$ at RT. Then the absorbance was taken at $517 \mathrm{~nm}$. The control was prepared as above without any sample. The scavenging activity was estimated based on the percentage of DPPH radical scavenged as the following equation:

$$
\begin{gathered}
\text { \%of DPPH radical scavenging activity } \\
=[\text { (control absorbance }- \text { sample absorbance }) \\
\quad /(\text { control absorbance })] \times 100
\end{gathered}
$$

\section{Determination of hydroxyl radical scavenging activity} Hydroxyl radical scavenging activity of the EPL-M80 was determined by the method described by Islam et al. [30]. The assay is based on the quantification of the degradation product of 2-deoxy-D-ribose by condensation with thiobarbituric acid (TBA). Hydroxyl radical was generated by the $\mathrm{Fe}^{3+}$ ascorbate-EDTA$\mathrm{H}_{2} \mathrm{O}_{2}$ system (the Fenton reaction). In a final volume of $1 \mathrm{~mL}$, the reaction mixture contained 2-deoxy-Dribose $(2.8 \mathrm{mM}) ; \mathrm{KH}_{2} \mathrm{PO}_{4}-\mathrm{KOH}$ buffer $(20 \mathrm{mM}$, pH 7 . 4); $\mathrm{FeCl}_{3}(100 \mu \mathrm{M})$; EDTA $(100 \mu \mathrm{M}) ; \mathrm{H}_{2} \mathrm{O}_{2}(1.0 \mu \mathrm{mM})$; AA $(100 \mu \mathrm{M})$; and various concentrations of the test sample or reference standard CA. After incubation for $1 \mathrm{~h}$ at $37{ }^{\circ} \mathrm{C}, 0.5 \mathrm{~mL}$ reaction mixture was added to $1 \mathrm{~mL}$ of $2.8 \%$ trichloroacetic acid, then $1 \mathrm{~mL}$ of $1 \%$ aqueous TBA was added, and the mixture was incubated at $90{ }^{\circ} \mathrm{C}$ for $15 \mathrm{~min}$ to develop the color. After it cooled, the mixture's absorbance was measured at $532 \mathrm{~nm}$ against an appropriate blank solution. The percentage (\%) of hydroxyl radical scavenging ability was calculated by using the following formula:

\%of hydroxyl radical scavenging activity

$$
\begin{gathered}
=\left(A_{\text {absorbance of control }}-A_{\text {absorbance of sample }}\right) \\
\left(A_{\text {absorbance of control }}\right) \times 100
\end{gathered}
$$




\section{Determination of cholinesterase inhibitory activity}

The AChE inhibitory assay was performed according to the colorimetric method by Ellman et al. [31] with acetylthiocholine iodide as a substrate. For the enzyme source, rat brains were homogenized by a homogenizer with five volumes of ice-cold homogenization buffer (10 $\mathrm{mM}$ Tris- $\mathrm{HCl}(\mathrm{pH} 7.2)$, which contained $1 \mathrm{M} \mathrm{NaCl}, 50$ $\mathrm{mM} \mathrm{MgCl} 2$ and $1 \%$ Triton X-100) and centrifuged at $10000 \mathrm{~g}$ for $30 \mathrm{~min}$. The resulting supernatant was used as an enzyme source. All of the extraction steps were carried out at $4{ }^{\circ} \mathrm{C}$. Protein concentration was determined by using a bicinchoninic acid kit (Sigma Co., St. Louis, MO, USA) with bovine serum albumin as a protein standard. The rates of hydrolysis by AChE were monitored spectrophotometrically. The EPL-M80 or standard $(500 \mu \mathrm{L})$ was mixed with an enzyme solution $(500 \mu \mathrm{L})$ and incubated at $37{ }^{\circ} \mathrm{C}$ for $15 \mathrm{~min}$. Absorbance was taken at $405 \mathrm{~nm}$ immediately after adding Ellman's reaction mixture $(3.5-\mathrm{mL} 0.5 \mathrm{mM}$ acetylthiocholine, 1

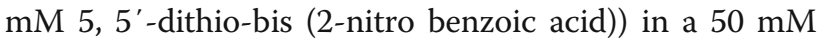
sodium phosphate buffer $(\mathrm{pH}$ 8.0) to the above reaction mixture. Readings were repeated for $10 \mathrm{~min}$ at $2 \mathrm{~min}$ intervals to verify that the reaction occurred linearly. The blank reaction was measured by substituting saline for the enzyme. Donepezil was used as a positive control. The percentage inhibition of AChE activity was calculated using the following formula:

$$
\begin{aligned}
& \text { \%of inhibition of AChE activity } \\
& =\left(\left(\mathrm{A}_{\text {absorbance of control }}-\mathrm{A}_{\mathrm{absorbance}} \text { of sample }\right)\right. \\
& \left.\quad / \mathrm{A}_{\text {absorbance of control }}\right) \times 100
\end{aligned}
$$

Assessment of BChE inhibition was performed as described above except that the enzyme solution was 50 $\mu \mathrm{L}$ and acetylthiocholine iodide was replaced by butyrylthiocholine iodide. Galantamine was used as positive control. The percentage inhibition of BChE activity was calculated using the same formula as mentioned above for AChE activity.

\section{Statistical analysis}

The data were analyzed by one-way ANOVA followed by Dunnet's test to estimate significant differences between the test and control groups with GraphPad Prism Data Editor for Windows, Version 6.0 (GraphPad Software Inc., San Diego, CA). Values were expressed as mean \pm standard error of mean $( \pm$ SEM). $p<0.05$ and $p$ $<0.01$ were considered as statistically significant.

\section{Results}

In vitro cholinesterase enzyme activity

The critical role of cholinesterases in neural transmission makes them a key target of a large number of

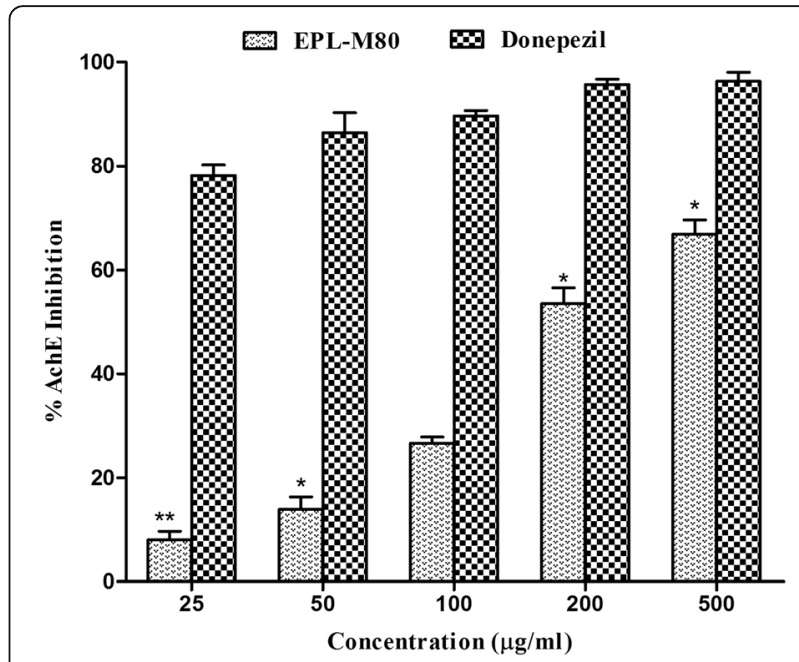

Fig. 1 Percentage of inhibition of acetylcholinesterase activity at different concentration of EPL-M80 and the reference standard donepezil. Results are presented as mean \pm SEM $(n=3)$. ${ }^{*} p<0.05$ and ${ }^{* *} p<0.01$ denote significant difference compared to the control

cholinesterase-inhibiting drugs relevant to the treatment of neurodegenerative disorders, including $\mathrm{AD}$. To evaluate the potential of the EPL-M80 as an anti-AD drug, its $\mathrm{AChE}$ and $\mathrm{BChE}$ inhibitory activities were quantified. As shown in Figs. 1 and 2, the EPL-M80 showed significant $(p<0.05) \mathrm{AChE}$ and BChE inhibitory effects when compared to the standards, and the cholinesterase inhibitory activity occurred in a dose-dependent manner. The AChE inhibitory activity of EPL-M80 was found to be 8 . $01 \pm 1.68,13.90 \pm 2.43,26.66 \pm 1.21,53.50 \pm 3.09$ and $66.82 \pm 2.79 \%$ at a concentration of $25,50,100,200$ and $500 \mu \mathrm{g} / \mathrm{mL}$, respectively, with $\mathrm{IC}_{50}$ of $165.40 \pm 4.01$

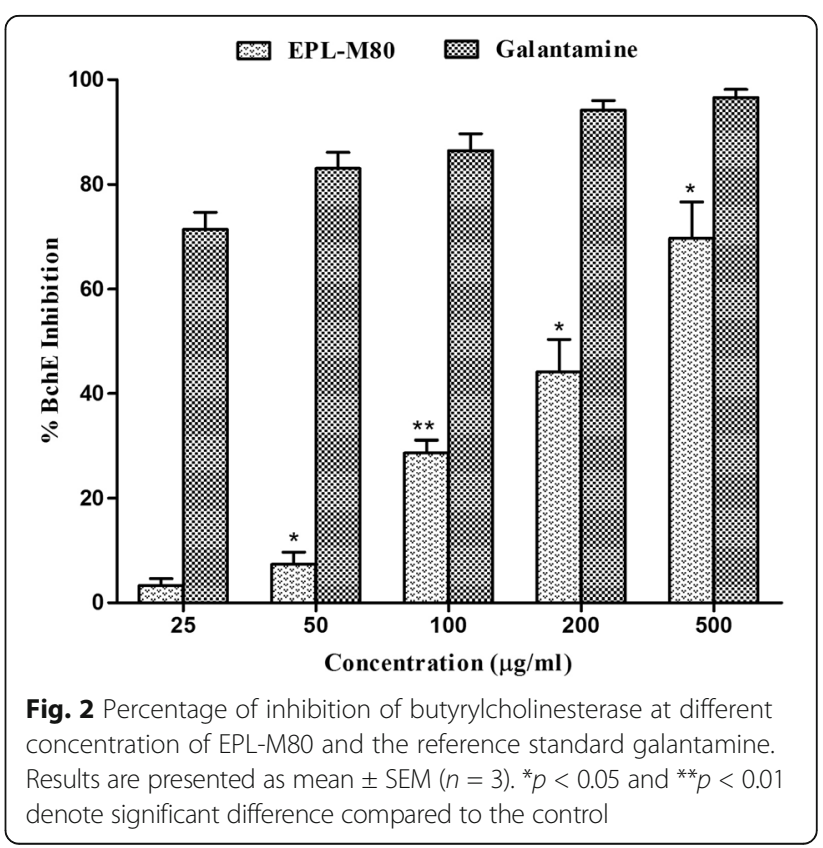


Table $1 \mathrm{IC}_{50}$ values of EPL-M80 and standards in radicals scavenging and enzymes inhibitory activity assays

\begin{tabular}{lllll}
\hline $\mathrm{IC}_{50} \mathrm{~S}(\mu \mathrm{g} / \mathrm{mL})$ & & & & \\
\hline Samples & DPPH radical scavenging & Hydroxyl radical scavenging & AChE & BChE \\
(+)-Catechin & $2.32 \pm 0.57^{\mathrm{a}}$ & $8.08 \pm 0.73$ & - & - \\
Donepezil & - & - & - & - \\
Galantamine & - & - & $17.01 \pm 0.33$ & $19.64 \pm 0.66$ \\
EPL-E80 & $32.35 \pm 0.68$ & $19.67 \pm 1.42$ & $213.81 \pm 3.57$ \\
\hline a
\end{tabular}

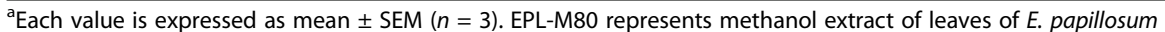

$\mu \mathrm{g} / \mathrm{mL}$ (Table 1). The BChE inhibitory activity of EPL-M80 was $3.24 \pm 1.34,7.31 \pm 2.35,28.67 \pm 2.39$, $44.14 \pm 6.19,69.70 \pm 6.92 \%$ at a concentration of 25 , 50, 100, 200 and $500 \mu \mathrm{g} / \mathrm{mL}$, respectively, with $\mathrm{IC}_{50}$ of $213.81 \pm 3.57 \mu \mathrm{g} / \mathrm{mL}$. In this study, donepezil and galantamine were used as reference standards. The $\mathrm{IC}_{50}$ of standard donepezil and galantamine against AChE and BChE were $17.01 \pm 0.33 \mu \mathrm{g} / \mathrm{ml}$ and 19.64 $\pm 0.66 \mu \mathrm{g} / \mathrm{mL}$, respectively (Table 1 ).

\section{DPPH free radical scavenging activity}

The in vitro antioxidant activity of the EPL-M80 was measured in comparison to the standard antioxidant, CA. However, the percentage of DPPH radical scavenging activity occurred in a dose-dependent manner. The EPL-M80 displayed higher scavenging activity (77.84 \pm $4.75 \%)$ with $\mathrm{IC}_{50}$ of $32.35 \pm 0.68 \mu \mathrm{g} / \mathrm{mL}$ than the standard CA $(93.98 \pm 2.37 \%)$ with $\mathrm{IC}_{50}$ of $2.32 \pm 0.57 \mu \mathrm{g} / \mathrm{mL}$ at the concentration of $100 \mu \mathrm{g} / \mathrm{mL}$ (Fig. 3 and Table 1), suggesting that EPL-M80 has the capacity to reduce OS caused by free radicals.

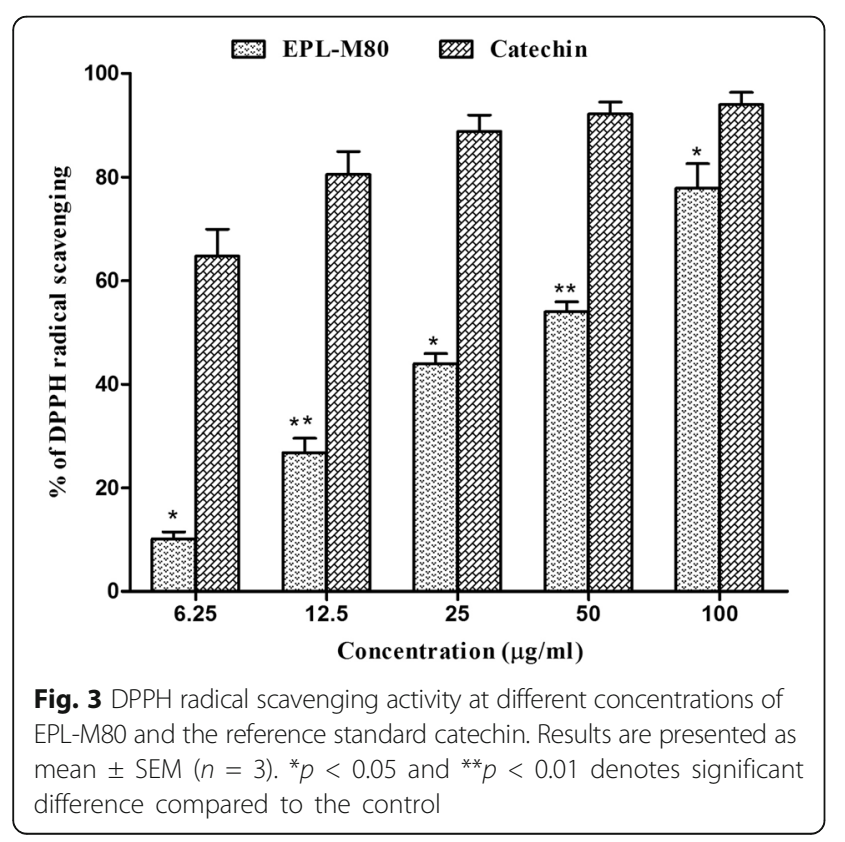

\section{Hydroxyl radical scavenging activity}

The hydroxyl radical is the major reactive oxygen species responsible for lipid oxidation and potentially severe biological damage. This assay shows how EPL-M80 and the standard CA inhibit hydroxyl radical-mediated deoxyribose degradation generated in a $\mathrm{Fe}^{3+}$ - ascorbate - EDTA - $\mathrm{H}_{2} \mathrm{O}_{2}$ system (the Fenton reaction). The hydroxyl radical scavenging capacity of the EPL-M80 and the standard CA were $73.31 \pm 4.17 \%$ with $\mathrm{IC}_{50}$ of $19.67 \pm 1.42 \mu \mathrm{g} / \mathrm{mL}$ ) and $78.47 \pm 3.81 \%$ with $\mathrm{IC}_{50}$ of $8.08 \pm 0.73 \mu \mathrm{g} / \mathrm{mL}$ ), respectively (Table 1). The results show EPL-M80 possesses similar capacity of hydroxyl radical scavenging to the standard CA (Fig. 4), suggesting EPL-M80 could provide a major source of antioxidant. Moreover, the ability of EPL-M80 to quench hydroxyl radicals might be of direct relevance to the prevention of lipid peroxidation.

\section{Total phenolic content}

The total phenolic content of EPL-M80 was ascertained by the method of Folin ciocalteu and calculated as gallic acid equivalent (GAE). The phenolic content of the EPLM80 was $23.74 \mathrm{mg}$ GAE /g of dry extract (Table 2).

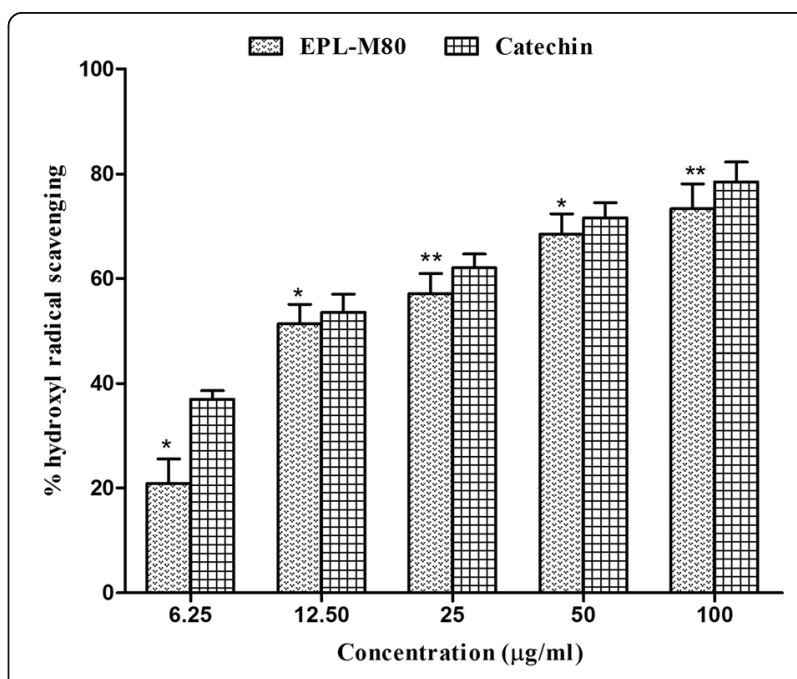

Fig. 4 Hydroxyl radical scavenging activity at different concentrations of EPL-M80 and the reference standard catechin. Results are presented as mean $\pm \operatorname{SEM}(n=3) .{ }^{*} p<0.05$ and ${ }^{* *} p<0.01$ denotes significant difference compared to the control 
Table 2 Polyphenol contents of EPL-M80

\begin{tabular}{ll}
\hline Polyphenols & EPL-M80 \\
\hline Phenolics $^{\mathrm{a}}$ & $23.74 \pm 0.04^{1}$ \\
Flavonoids $^{\mathrm{b}}$ & $31.18 \pm 0.01$ \\
\hline
\end{tabular}

NB: 'Each value is the average of three analyses \pm standard deviation. $a$ and $b$ expressed in terms of GAE and CAE, respectively ( $\mathrm{mg}$ of GA and CA / $\mathrm{g}$ of dry extract, respectively). EPL-M80 represents methanol extract of leaves of E. papillosum

\section{Total flavonoid content}

The aluminum chloride colorimetric method was adopted for the assessment of total flavonoid content. The content of total flavonoids was expressed as catechin equivalent (CAE). The flavonoid content of the EPL-M80 was 31.18 mg CAE/ g of dry extract (Table 2).

\section{Correlation and regression of phenolic contents with antioxidant and anticholinesterase potential}

Table 3 shows the correlation and regression $(p<0.001)$ of phenolic contents with respect of antioxidant and anticholinesterase potential. A significant correlation $(p<$ 0.001) was observed for EPL-M80.

\section{Discussion}

Alzheimer's disease (AD) is a chronic neurodegenerative disorder characterized by the progressive impairment of memory, cognition and behavior that usually exhibits a slow onset before worsening over time and ultimately leading to death. The causes of $\mathrm{AD}$ are poorly understood [32], although several etiological factors, such as genetic abnormalities [33], history of head injuries, environmental factors, general lifestyles [34], depression or hypertension [32], deposition of extracellular $\beta$-amyloid protein $(\mathrm{A} \beta)$ and microtubule associated tau protein [33] in the brain, and cholinergic dysfunction have all been implicated in AD. At present, there are no drugs available that are capable of curing Alzheimer's disease or any of the other common types of dementia, but two conceptual approaches for the treatment of $\mathrm{AD}$ have been developed. The first approach consists of treatment to avert the onset of the disease by sequestering the primary progenitors in order to prevent the development of AD. The second approach involves symptomatic

Table 3 Correlation coefficients between the total phenolic contents and antioxidant as well as cholinesterase inhibitory activity of EPL-M80

\begin{tabular}{lllll}
\hline \multicolumn{4}{l}{ Total Phenolic Contents $\left(\right.$ Correlation R $\left.{ }^{2}\right)$} \\
\hline Assays & DPPH & HRSA & AChEl & BChEl \\
EPL-M80 & ${ }^{1} 0.998^{* *}$ & $0.969^{* *}$ & $0.978^{* *}$ & $0.855^{*}$ \\
\hline
\end{tabular}

${ }^{1}$ Each value is represented as mean $\pm \mathrm{SD}(n=3) .{ }^{*}$ indicates significance at ${ }^{*} P$ $<0.05,{ }^{* * *} P<0.01$. DPPH $=2,2$-diphenyl-1-picrylhydrazyl, HRSA = hydroxyl radical scavenging assay, $\mathrm{AChEI}=$ Acetylcholinesterase inhibition and $\mathrm{BChEI}=$ Butyrylcholinesterase inhibition. EPL-M80 represents methanol extract of leaves of E. papillosum treatment of the tertiary cognitive symptoms of the disease to protect against further cognitive decline [35]. However, the implementation of appropriate treatment strategies depends on the severity of the disease and the specificity of each individual case. Currently, only three cholinesterase inhibitors such as donepezil, galantamine, rivasigmine and a patial NMDA receptor antagonist, memantine, are the Food and Drug Administration (FDA) approved drugs to treat $\mathrm{AD}$. The purpose of cholinesterase inhibitors is to inhibit the degradation of acetylcholine within synapses, resulting in increased amount of acetylcholine. Memantine, which is a partial NMDA receptor antagonist, protects neurons from glutamate-induced excitatory damages [1]. These strategies represent the only current treatments available for $\mathrm{AD}$. The cholinesterase inhibitors employed in current treatments are limited and they show a wide variety of toxic effect including insomnia, anorexia, diarrhea, fatigue, nausea, gastrointestinal disorders and cardiovascular disorders [1, 2]. Therefore, researchers have focused their attention towards the discovery of new drugs from natural sources such as plants, which have enormous potential for the treatment of $\mathrm{AD}$. In this study, we have discovered the capacity of EPL-M80 to significantly inhibit $\mathrm{AChE}$ and $\mathrm{BChE}$ activities in a dosedependent manner (Figs. 1 and 2). The inhibition of cholinesterases was found to be better compared to other medicinal plants including Andrographis paniculata, Nelumbo nucifera, Myrstica fragrans, and Aegle marmelos [2, 7] suggesting EPL-M80 extract as an effective cholinesterase inhibitor and can be used in the treatment of AD [5].

Accumulating evidence suggests that brain tissues in $\mathrm{AD}$ patients are exposed to OS during the development of the disease. The biological damage caused by OS includes protein oxidation, lipid oxidation, DNA oxidation and glycoxidation [36] which are closely associated with the development of $\mathrm{AD}$, cancer, diabetes etc. [37]. OS is generally characterized by an imbalanced production of ROS and reactive nitrogen species (RNS). OS is initiated by free radicals such as the superoxide anion radical $\left(\mathrm{O}_{2}{ }^{\cdot-}\right)$, hydrogen peroxide $\left(\mathrm{H}_{2} \mathrm{O}_{2}\right)$, the hydroxyl radical $(\cdot \mathrm{OH})$, singlet oxygen $\left({ }^{1} \mathrm{O}_{2}\right)$, alkoxyl radicals (RO.) and peroxyl radicals (ROO•), which have a tendency to become stable through electron pairing with biological macromolecules like proteins, lipids and DNA in healthy human cells. This tendency has led to the assertion that OS contribute to the pathogenesis of numerous human degenerative diseases [38, 39]. Antioxidative defense systems act to remove ROS and prevent cellular damage by quenching free radicals, thereby protecting against diseases such as AD [40]. Such defense systems play a vital role in protecting living organisms from the damaging effects of free radical 
attacks, however, extensive biological damage can occur when the rate of free radical generation exceeds the capacity of this defensive system, leading to elevated ROS levels [41]. Elevated levels of ROS contribute to the pathogenesis observed during the course of $\mathrm{AD}$. Therefore, we quantified the scavenging potential of EPLM80 using the DPPH bleaching assay for antioxidant activity [42]. In this assay, the extent of color change is proportional to the potential and concentration of antioxidant activity, conferred by the hydrogen donating ability [43]. In our study, EPL-M80 showed high scavenging percentage of DPPH, reflecting its potent antioxidant activity (Fig. 3). The hydroxyl radical is an extremely damaging ROS formed by successive monovalent reduction of dioxygen $\left(\mathrm{O}_{2}\right)$, capable of initiating lipid peroxidation which results in severe cell damage in vivo [44]. The short-lived hydroxyl radical is particularly damaging to the polyunsaturated fatty acid of cell membrane phospholipids with harmful effect to the cell [45]. Hydroxyl radicals are generated in the biological system by the Fenton reaction with subsequent degradation of deoxyribose to TBARS which generates a pink chromogen on heating at low $\mathrm{pH}$ with TBA [46]. In our investigation, EPL-M80 showed promising hydroxyl radical scavenging activity and was capable of protecting deoxyribose in a dose-dependent manner. There is evidence that the hydroxyl radical activity of the extract is directly proportional to its antioxidant activity [47] (Fig. 4). In biological systems, aberrant production of free radicals lead to extensive tissue and bio-molecules damage, which in turn cause a multitude of degenerative diseases $[8,48]$. Phenolic and flavonoid compounds represent classes of antioxidant capable of acting as free radical scavenger $[49,50]$ to prevent cellular damage. In our study, we detected a cumulative increase of phenolic and flavonoid contents with increasing concentration of EPLM80, suggesting that EPL-M80 is capable of reducing the risk of various degenerative diseases including $\mathrm{AD}$, by eliciting antioxidative activities to prevent OS damage (Table 2). Previous studies also revealed that flavonoids act as free radical scavengers of many oxidizing species [51]. Total phenolic contents of EPL-M80 showed significant and strong positive correlation $(p<0.001)$ with antioxidants (DPPH and $\mathrm{OH}$ ) and anticholinesterase (AChE and $\mathrm{BChE}$ ) potential (Table 3). These results suggest a potential role of the polyphenolic constituents of EPLM80 in free radical neutralization and inhibition of $\mathrm{ChE}$ activity. Further studies are warranted to isolate and characterize the active polyphenol compound that may be used as a candidate drug in $\mathrm{AD}$.

\section{Conclusion}

To the best of our knowledge, this is the first report describing the cholinergic inhibitory and antioxidant activities of Elatostema papillosum. However, further testing in an animal model of Alzheimer's disease is needed to clarify the in vivo effectiveness of this plant.

\section{Acknowledgments}

The authors are grateful to the Department of Pharmacy, International Islamic University Chittagong, Bangladesh for providing necessary facilities for this research work. The authors also acknowledge Mr. George Hunt, PhD student, Stockholm University, Sweden, for comments and grammatical corrections on this manuscript.

\section{Funding}

The authors declare that they have no fund for this research.

\section{Availability of data and materials}

All data generated or analysed during this study are included in this published article.

\section{Authors' contributions}

ASMAR, MSH, SA, MSN and MRR carried out the experiments and wrote the manuscript. GS, MJU supervised the work and prepared the manuscript. AHMKA worked on correlation and regression analysis, and contributed to the manuscript writing and corrections. All authors read and approved the final manuscript. All authors read and approved the final manuscript.

\section{Ethics approval and consent to participate}

Protocol used in this study for the use of rat as animal model for AD research was approved by the Rajshahi University Animal Ethical committee (27/08/RUBCMB). This research work was approved by Ethical Review Committee of Research Cell of Rajshahi Medical College, Bangladesh (ref. RMC/ER/2010-2013/01).

\section{Consent for publication}

Not applicable.

\section{Competing interests}

The authors declare that they have no competing interests.

\section{Publisher's Note}

Springer Nature remains neutral with regard to jurisdictional claims in published maps and institutional affiliations.

\section{Author details}

'Department of Pharmacy, Faculty of Science and Engineering, International Islamic University Chittagong, Chittagong 4318, Bangladesh. ${ }^{2}$ Department of Applied Nutrition and Food Technology, Islamic University, Kushtia 7003, Bangladesh. ${ }^{3}$ Department of Pharmacy, University of Rajshahi, Rajshahi 6205, Bangladesh.

Received: 29 June 2017 Accepted: 21 March 2018

Published online: 05 April 2018

\section{References}

1. Fratiglioni L, Winblad B, von Strauss E. Prevention of Alzheimer's disease and dementia. Major findings from the Kungsholmen project. Physiol Behav. 2007;92(1):98-104

2. Asaduzzaman M, Uddin M, Kader M, Alam A, Rahman AA, Rashid M, Kato K, Tanaka T, Takeda M, Sadik G. In vitro acetylcholinesterase inhibitory activity and the antioxidant properties of Aegle marmelos leaf extract: implications for the treatment of Alzheimer's disease. Psychogeriatrics. 2014;14(1):1-10.

3. Varadarajan S, Yatin S, Aksenova M, Butterfield DA. Review: Alzheimer's amyloid $\beta$-peptide-associated free radical oxidative stress and neurotoxicity. J Struct Biol. 2000;130(2-3):184-208.

4. Vinutha B, Prashanth D, Salma K, Sreeja S, Pratiti D, Padmaja R, Radhika S, Amit A, Venkateshwarlu K, Deepak M. Screening of selected Indian medicinal plants for acetylcholinesterase inhibitory activity. J Ethnopharmacol. 2007;109(2):359-63.

5. Bierer LM, Haroutunian V, Gabriel S, Knott PJ, Carlin LS, Purohit DP, Perl DP, Schmeidler J, Kanof P, Davis KL. Neurochemical correlates of dementia severity in Alzheimer's disease: relative importance of the cholinergic deficits. J Neurochem. 1995;64(2):749-60. 
6. Mukherjee PK, Kumar V, Mal M, Houghton PJ. Acetylcholinesterase inhibitors from plants. Phytomedicine. 2007;14(4):289-300.

7. López V, MartÃn S, Gómez-Serranillos MP, Carretero ME, Jäger AK, Calvo MI. Neuroprotective and neurological properties of Melissa officinalis. Neurochem Res. 2009;34(11):1955-61.

8. Halliwell B, Gutteridge JM. Free radicals in biology and medicine. USA: Oxford University Press; 2015

9. Matsuda T, Kanki T, Tanimura T, Kang D, Matsuura ET. Effects of overexpression of mitochondrial transcription factor a on lifespan and oxidative stress response in Drosophila melanogaster. Biochem Biophys Res Commun. 2013;430(2):717-21.

10. Mamelona J, Pelletier Ã\%o, Girard-Lalancette K, Legault J, Karboune S, Kermasha S. Quantification of phenolic contents and antioxidant capacity of Atlantic Sea cucumber, Cucumaria frondosa. Food Chem. 2007;104(3):1040-7.

11. Tang Y, Gao C, Xing M, Li Y, Zhu L, Wang D, Yang X, Liu L, Yao P. Quercetin prevents ethanol-induced dyslipidemia and mitochondrial oxidative damage. Food Chem Toxicol. 2012;50(5):1194-200.

12. Gutzmann H, Hadler D. Sustained efficacy and safety of idebenone in the treatment of Alzheimer's disease: update on a 2-year double-blind multicentre study. In: Alzheimer's Disease-From Basic Research to Clinical Applications: Journal of Neural Transmission Supplementa, vol. 54. Vienna: Springer; 1998. p. 301-10

13. Houghton P, Howes M-J, Lee C, Steventon G. Uses and abuses of in vitro tests in ethnopharmacology: visualizing an elephant. J Ethnopharmacol. 2007;110(3):391-400

14. Nordberg A, Svensson A-L. Cholinesterase inhibitors in the treatment of Alzheimer's disease. Drug Saf. 1998;19(6):465-80.

15. Schulz V. Ginkgo extract or cholinesterase inhibitors in patients with dementia: what clinical trials and guidelines fail to consider. Phytomedicine. 2003;10:74-9.

16. Small GW, Rabins PV, Barry PP, Buckholtz NS, DeKosky ST, Ferris SH, Finkel SI, Gwyther LP, Khachaturian ZS, Lebowitz BD. Diagnosis and treatment of Alzheimer disease and related disorders: consensus statement of the American Association for Geriatric Psychiatry, the Alzheimer's Association, and the American Geriatrics Society. JAMA. 1997;278(16):1363-71.

17. Melzer D. New drug treatment for Alzheimer's disease: lessons for healthcare policy. BMJ. 1998;316(7133):762.

18. Wichi $\mathrm{H}$. Enhanced tumor development by butylated hydroxyanisole (BHA) from the prospective of effect on forestomach and oesophageal squamous epithelium. Food Chem Toxicol. 1988;26:717-23.

19. Murray AP, Faraoni MB, Castro MJ, Alza NP, Cavallaro V. Natural AChE inhibitors from plants and their contribution to Alzheimer's disease therapy. Curr Neuropharmacol. 2013;11(4):388-413.

20. Yahara T. Pellionia and Elatostema in Thailand. Journal of the Faculty of Science, University of Tokyo, Section III. Botany. 1984;13:483-99.

21. Rahman MA, Uddin S, Wilcock C. Medicinal plants used by Chakma tribe in hill tracts districts of Bangladesh. 2007.

22. Ploton L. From hysteria to Alzheimer's disease: the function of the symptom. Cliniques méditerranéennes. 2009;1:63-77.

23. Zimmermann M. Ethical guidelines for investigations of experimental pain in conscious animals. Pain. 1983;16(2):109-10.

24. Leary SL, Underwood W, Anthony R, Gwaltney-Brant S, Poison A, Meyer R. AVMA guidelines for the euthanasia of animals: 2013 edition. Schaumburg American Veterinary Medical Association; 2013

25. Allen-Worthington KH, Brice AK, Marx JO, Hankenson FC. Intraperitoneal injection of ethanol for the euthanasia of laboratory mice (Mus musculus) and rats (Rattus norvegicus). J Am Assoc Lab Anim Sci. 2015;54(6):769-78.

26. Kim D-O, Jeong SW, Lee CY. Antioxidant capacity of phenolic phytochemicals from various cultivars of plums. Food Chem. 2003;81(3):3216

27. Yang J, Paulino R, Janke-Stedronsky S, Abawi F. Free-radical-scavenging activity and total phenols of noni (Morinda citrifolia L.) juice and powder in processing and storage. Food Chem. 2007;102(1):302-8.

28. Brand-Williams W, Cuvelier M-E, Berset C. Use of a free radical method to evaluate antioxidant activity. LWT- Food Sci. Technol. 1995;28(1):25-30.

29. Bursal E, Gülçin I. Polyphenol contents and in vitro antioxidant activities of lyophilised aqueous extract of kiwifruit (Actinidia deliciosa). Food Res Int. 2011;44(5):1482-9.

30. Islam S, Nasrin S, Khan MA, Hossain AS, Islam F, Khandokhar P, Mollah MNH, Rashid M, Sadik G, Rahman MAA. Evaluation of antioxidant and anticancer properties of the seed extracts of Syzygium fruticosum Roxb. Growing in Rajshahi, Bangladesh. BMC Complement Altern Med. 2013;13(1):142.

31. Ellman GL, Courtney KD, Andres V, Featherstone RM. A new and rapid colorimetric determination of acetylcholinesterase activity. Biochem Pharmacol. 1961;7(2):88IN191-9095

32. Burns A. lliffe S ((2009)) Alzheimer's disease. BMJ. 338:b158.

33. Ballard C, Gauthier S, Corbett A, Brayne C, Aarsland D, Jones E. Alzheimer's disease. Lancet. 377(9770):1019-31.

34. Kalaria R, Maestre G, Arizaga R, Friedland R, Galasko D, Hall K, Luchsinger J, Ogunniyi A, Perry E, Potocnik F, World Federation of Neurology Dementia Research Group. Alzheimer's disease and vascular dementia in developing countries: prevalence, management, and risk factors. Lancet Neurol. 2008; 7(9):812-26.

35. Feng $Y$, Wang $X$. Antioxidant therapies for Alzheimer's disease. Oxidative Med Cell Longev. 2012;2012

36. Nunomura A, Castellani RJ, Zhu X, Moreira PI, Perry G, Smith MA. Involvement of oxidative stress in Alzheimer disease. J Neuropathol Exp Neurol. 2006;65(7):631-41.

37. Shahwar D, Raza MA. Antioxidant potential of phenolic extracts of Mimusops elengi. Asian Pac J Trop Biomed. 2012;2(7):547-50.

38. Jung HA, Min B-S, Yokozawa T, Lee J-H, Kim YS, Choi JS. Anti-Alzheimer and antioxidant activities of Coptidis Rhizoma alkaloids. Biol Pharm Bull. 2009; 32(8):1433-8

39. Hossain MS, Reza AA, Rahaman MM, Nasrin MS, Rahat MRU, Islam MR, Uddin MJ, Rahman MA. Evaluation of morning glory (Jacquemontia tamnifolia (L.) Griseb) leaves for antioxidant, antinociceptive, anticoagulant and cytotoxic activities. J Basic Clin Physiol Pharmacol. 2018;28(3):1-9.

40. Braca A, Sortino C, Politi M, Morelli I, Mendez J. Antioxidant activity of flavonoids from Licania licaniaeflora. J Ethnopharmacol. 2002;79(3):379-81.

41. Hasan SR, Hossain MM, Akter R, Jamila M, Mazumder MEH, Rahman S. DPPH free radical scavenging activity of some Bangladeshi medicinal plants. J Med Plants Res. 2009;3(11):875-9.

42. Nunes XP, Silva FS, JRGDS A, Barbosa Filho JM, de Lima JT, de Araújo Ribeiro LA, LJQ J. Biological oxidations and antioxidant activity of natural products: Phytochemicals as nutraceuticals-Global Approaches to Their Role in Nutrition and Health. London: InTech.; 2012.

43. Von Gadow A, Joubert E, Hansmann C. Comparison of the antioxidant activity of rooibos tea (Aspalathus linearis) with green, oolong and black tea. Food Chem. 1997:60(1):73-7.

44. Duan X, Wu G, Jiang Y. Evaluation of the antioxidant properties of litchi fruit phenolics in relation to pericarp browning prevention. Molecules. 2007; 12(4):759-71.

45. Halliwell B, Gutteridge JM. Formation of a thiobarbituric-acid-reactive substance from deoxyribose in the presence of iron salts: the role of superoxide and hydroxyl radicals. FEBS Lett. 1981;128(2):347-52.

46. Halliwell B, Gutteridge JM, Aruoma OI. The deoxyribose method: a simple "test-tube" assay for determination of rate constants for reactions of hydroxyl radicals. Anal Biochem. 1987;165(1):215-9.

47. Gülçin İ, Berashvili D, Gepdiremen A. Antiradical and antioxidant activity of total anthocyanins from Perilla pankinensis decne. J Ethnopharmacol. 2005 101(1):287-93.

48. Rahman M, Rahman A. Antinociceptive, anxiolytic and sedative effects of methanol extract of Anisomeles indica: an experimental assessment in mice and computer aided models. Front Pharmacol. 2018;9:246.

49. Shahidi F, Janitha P. Wanasundara P. Phenolic antioxidants. Crit Rev Food Sci Nutr. 1992;32(1):67-103.

50. Islam MR, Reza AA, Chawdhury KAA, Uddin J, Farhana K. Evaluation of in vitro antioxidant activity and cytotoxicity of methanolic extract of Sida cordata leaves. Int J Biol Pharm Res. 2014:5(2):196-200.

51. Bravo L. Polyphenols: chemistry, dietary sources, metabolism, and nutritional significance. Nutr Rev. 1998:56(11):317-33. 